\title{
Upaya Meningkatkan Motivasi dan Hasil Belajar Siswa Pada Materi Membaca Menggunakan Alat Peraga Kartu Huruf Dengan Penerapan Tematik di Kelas I
}

\section{Sarimani}

\begin{abstract}
Abstrak
Penelitian ini dilatarbelakangi oleh kesulitas guru dalam membantu siswa memahami huruf untuk membaca. Apalagi kepada siswa yang belum pernah mengikuti pendidikan di TK. Untuk mengatasi hal tersebut guru menggunakan kartu huruf berwarna. Tujuan penelitian ini adalah untuk menggambarkan penggunaan alat peraga dalam pembelajaran membaca. Penelitian ini merupakan penelitian tindakan kelas. Subjek penelitian ini adalah siswa SD kelas I pada SDN 08 Nan Sabaris. Data yang diperoleh menunjukkan bahwa dengan menggunakan alat bantu berupa kartu huruf dapat meningkatkan keterampilan siswa dalam membaca dan juga dapat meningkatkan hasil belajar mereka. Hal ini dibuktikan dengan hasil analisis data, diperoleh keberhasilan belajar pada prasiklus perolehan hasil evaluasi hanya 50,10 dan pada siklus I; $62,00 \%$, dan pada siklus II; sebesar $82,60 \%$. Hal ini menunjukkan ada peningkatan pembelajaran siswa dari siklus I sampai siklus II.
\end{abstract}

Kata Kunci: Motivasi, hasil belajar, alat peraga kartu huruf, tematik

\section{PENDAHULUAN}

Bahasa adalah sistem lambang yang berwujud bunyi atau bunyi ujar yang bisa diucapkan melalui apa yang tertulis atau apa yang dilihat. "Membaca merupakan suatu proses menyusun huruf demi huruf yang bermakna, yang kemudian bisa dilukiskan lambang-lambang grafik yang menggambarkan suatu bahasa yang dapat dipahami orang lain" (Sumanto, 1987:21). Wardana (1990:15) berpendapat bahwa "membaca adalah keseluruhan rangkaian kegiatan seseorang dalam menyebutkan simbol yang tertulis dalam bahasa tulis yang mempunyai arti sesuai dengan lambang atau huruf yang ditulis, sehingga seseorang akan bisa menangkap makna dari apa yang tertera".

Membaca merupakan kegiatan untuk membuka jendela dunia. Melalui membaca seseorang dapat mempelajari ilmu pengetahuan lainnya. Oleh karena itu sangat penting bagi siswa untuk mempelajari membaca ini. Pembelajaran membaca sudah dimulai sejak siswa kelas I SD. Salah satu langkah yang dapat dilakukan guru untuk mempermudah siswa belajar membaca dengan mengenalkan huruf. Guru cukup sulit mengenalkan huruf kepada siswa, apalagi kepada mereka yang belum pernah mengikuti pendidikan di Taman Kanak-Kanak (TK). Selain itu berdasarkan tes tes awal yang dilaksanakan pada awal Maret 2015 diperoleh nilai rata-rata membaca sebesar 51,00. Hasil ini masih dibawah Kriteria Ketuntasan Minimal (KKM) yang sudah ditetapkan yakni 75,00. Skala data itu menunjukkan bahwa siswa kurang mempunyai kemampuan dalam membaca kata/huruf yang tertulis. Siswa kurang mampu membaca dengan lancar atau masih mengeja/terbata-bata. Hasil penilaian tersebut menunjukkan juga bahwa motivasi siswa dalam belajar masih rendah. Hal ini sesuai dengan pendapat Azwar $(200 ; 15)$ Motivasi adalah rangsangan, dorongan ataupun pembangkit tenaga yang dimiliki seseorang ataupun sekelompok masyarakat yang mau berbuat dan bekerja secara optimal dalam melaksanakan sesuatu yang telah direncanakan untuk mencapai tujuan yang telah direncanakan Untuk mempermudah siswa mengenal huruf, sebaiknya guru menggunakan alat peraga yang menarik. Salah satu alat peraga yang dapat digunakan adalah kartu huruf warna warni. Kartu huruf dalam KBBI, Balai Pustaka (h.448) merupakan kertas tebal yang berbentuk persegi panjang, sedangkan huruf KBBI, Balai Pustaka (h.362) adalah tanda aksara atau tata tulis yang merupakan abjad yang melambangkan bunyi 
bahasa dan aksara. Kartu huruf dalam penelitian ini adalah kartu huruf yang terbuat dari bahan plastik dan di belakang huruf-huruf tersebut ada magnet yang bisa ditempelkan di papan khusus yang disediakan di sekolah.

Berdasarkan analisis latar belakang masalah maka rumusan masalah dalam penelitian ini adalah bagaimanakah upaya dalam meningkatkan motivasi dan hasil belajar siswa pada materi membaca menggunakan alat peraga kartu huruf dengan penerapan tematik di kelas I.

\section{METODOLOGI PENELITIAN}

Penelitian ini adalah penelitian tindakan kelas (classroom action research), dilaksanakan di kelas I SDN 08 Nan Sabaris. Subjek penelitiannya berjumlah 25 orang, yang terdiri dari 15 orang laki-laki dan 10 orang perempuan. Lewin (dalam Kemmins dan McTaggart, 1988) mendeskripsikan Penelitian Tindakan Kelas sebagai tindakan berkelanjutan dari langkah-langkah berbentuk spiral, setiap langkah (siklus) berisi perencanaan, pelaksanaan tindakan, observasi (evaluasi), dan refleksi tindakan.

Penelitian ini berlangsung dalam 2 siklus. Setiap siklus terdiri atas 4 tahap, yaitu (1) tahap perencanaan, meliputi : pembekalan kepada guru, penyusunan model pembelajaran, penyiapan instrumen tes (pretes, postes), lembar observasi dan membentuk kelompok belajar siswa, (2) tahap pelaksanaan tindakan, meliputi: pelaksanaan kegiatan dari perencanaan yang dibuat, (3) tahap observasi, yaitu pengamatan dari pelaksanaan tindakan melalui pedoman observasi, dan (4) tahap refleksi, yaitu menganalisis dan memberi pemaknaan dari pelaksanaan tindakan, sehingga dapat dibuat perencanaan tindakan pada siklus berikutnya.

Data dalam penelitian ini dikumpulkan dengan menggunakan alat tes dan pedoman observasi. Tes digunakan untuk memperoleh data tentang peningkatan kemampuan dan motivasi membaca. Tes yang digunakan terdiri atas 10-20 suku kata pada setiap siklus, sehingga jumlah soal dari kedua siklus berjumlah 40 suku kata. Agar dalam penyusunan tes dapat mengukur aspek yang diperlukan dan sesuai dengan tema yang diajarkan, maka terlebih dahulu disusun kisi-kisi tes (Sudjana, 1989). Siswa yang dianggap tuntas belajar bila telah mencapai nilai 75 ke atas, siswa yang dapat nilai kurang dari 75 dinyatakan belum tuntas belajar. Post-tes dilaksanakan pada setiap akhir siklus, sedangkan untuk mengamati kegiatan guru dan siswa digunakan pedoman observasi. Untuk mendukung hasil pengamatan, peneliti juga melakukan perekaman kegiatan proses pembelajaran dengan menggunakan kamera foto.

Data yang telah terkumpul dianalisis dengan rumus persentase. Selanjutnya, nilai yang diperoleh siswa dicocokkan ke dalam tabel konversi nilai dengan skala 5. Hasil analisis ini digunakan untuk mencari ketuntasan belajar. Menurut Depdikbud (1994) ketuntasan belajar secara klasikal sebesar 85\%, dari siswa memperoleh nilai 70 atau $70 \%$, artinya siswa baru dapat dikatakan tuntas bila siswa telah mendapat nilai minimal 70. Bila siswa memperoleh nilai kurang dari 70 dianggap belum tuntas belajar, selanjutnya bagi siswa yang bersangkutan dimasukkan ke dalam 1 atau 2 kelompok tergantung dari jumlah siswa yang belum tuntas belajar. Siswa inilah yang mendapatkan perhatian (fokus) dari guru saat pelaksanaan tindakan pada siklus-siklus berikutnya.

\section{HASIL DAN PEMBAHASAN PENELITIAN Hasil Penelitian Siklus I Perencanaan}

Perencanaan penelitian tindakan kelas pada siklus I mengikuti langkah-langkah esensialnya yakni siswa diminta mengambil kartu huruf berwarna secara acak yang telah disediakan guru. Guru meminta siswa mengambil kartu huruf konsonan, vocal, konsonan, vocal hingga tersusun kata berpola KV-KV, kemudian siswa diminta untuk membaca kata yang terbentuk berulang-ulang untuk melatih kemampuan dan memperkaya kosa kata pada anak.

\section{Pelaksanaan Penelitian}

Pelaksanaan pembelajaran di sesuaikan dengan perencanaan yang telah dibuat. Kegiatan pembelajaran di awali dengan diskusi dan tanyajawab tentang aktivitas siswa sebelum berangkat ke sekolah. Hal ini untuk membantu siswa menambah kosakata dalam menyusun kartu huruf menjadi kata. Kegiatan berikutnya siswa mengambil kartu huruf secara acak. Guru meminta siswa untuk menyusun kartu huruf itu dengan pola konsonan vocal, konsonan vocal. Setelah itu siswa di minta untuk membacakan kartu huruf yang telah di susunnya. Guru meminta pendapat siswa lain jika kartu huruf siswa tersebut tidak membentuk satu 
kata. Hal ini agar siswa belajar konsentrasi dalam kegiatan pembelajaran yang dilaksanakan dan menambah kosa kata mereka. Setelah itu guru membuat rangkuman tentang pembelajaran yang dilaksanakan.

\section{Hasil Pengamatan}

Pengamatan pembelajaran dilihat dari dua sisi yaitu proses dan hasil belajar. Proses diperoleh dari pengamatan kolaborator dan catatan lapangan peneliti sedangkan hasil belajar diperoleh dari nilai evaluasi belajar siswa. Pengamatan pada proses pelajaran dapat diketahui beberapa hal terhadap pelaksanaan pembelajaran. Hasil pengamatan pada siklus I sebagai berikut, (a) guru telah memulai pelajaran dengan memberi motivasi pada siswa. Motivasi yang diberikan guru berbentuk pertanyaan dan diskusi tentang aktivitas mereka sebelum berangkat sekolah. Jawaban yang diberikan siswa dari pertanyaan-pertanyaan guru lebih banyak dijawab siswa secara serempak. Hal ini membuktikan bahwa kemampuan guru dalam memberikan pertanyaan perlu diperbaiki. Saat mengakhiri kegiatan, guru membuat rangkuman dan didengar oleh siswa. Sebaiknya guru bersama-sama siswa membuat rangkuman. Siswa harus dibimbing guru menemukan kesimpulan dari kegiatan belajar yang telah diikuti. (b) pada saat siswa menyusun kartu huruf, waktu yang diberikan guru terlalu sempit dan terkesan terburu-buru. Guru juga tidak sempat mencek keberhasilan semua siswa dalam menyusun kartu huruf. (c) saat guru meminta pendapat siswa terhadap susunan kartu huruf temannya yang salah, guru kurang sabar dan tidak memberi waktu yang cukup untuk berfikir.

Pada Siklus I perolehan nilai belajar siswa rata-rata 61,50. Hanya 7 orang dari 25 orang siswa yang tuntas sesuai dengan KKM yang telah ditetapkan. Berdasarkan data dari hasil evaluasi kegiatan yang dilakukan oleh peneliti, dapat didistribusikan data hasil belajar dalam kegiatan pada siklus I sebagai berikut.

Tabel 1

Distribusi Hasil Belajar Secara Persentase Dari Siswa Kelas I SDN 08 Nan Sabaris T.P 2015/2016

\begin{tabular}{ccccc} 
No & Nilai & Frekuensi & \% Frekuensi & Kategori Motivasi \\
\hline $\mathbf{1}$ & 100 & - & $0,00 \%$ & Sangat Tinggi \\
$\mathbf{2}$ & 90 & - & $0,00 \%$ & Tinggi \\
$\mathbf{3}$ & 80 & 4 & $16 \%$ & Cukup Tinggi \\
$\mathbf{4}$ & 70 & 4 & $16 \%$ & Sedang \\
$\mathbf{5}$ & 60 & 10 & $40 \%$ & Cukup \\
$\mathbf{6}$ & 50 & 7 & $28 \%$ & Kurang \\
\hline
\end{tabular}

Dari frekuensi data tersebut diketahui kategori kurang dalam prestasi belajar adalah nilai 50 dengan frekuensi 7 dan persentase 28\%, kategori nilai sedang adalah nilai 60 dengan frekuensi 10 dan persentase $40 \%$, sedangkan kategori hasil belajar cukup adalah nilai 70 dengan frekuensi 4 dan persentase 16\%, nilai cukup baik adalah 80 dengan frekuensi 4 dan persentase 16\%, nilai baik adalah 90 dan nilai sangat baik adalah 100 tidak ada. Analisis hasil belajar juga terlihat bahwa motivasi siswa dalam belajar menggunakan alat peraga kartu huruf cukup tinggi.

\section{Refleksi}

Berdasarkan hasil pengamatan di temukan beberapa kelemahan tindakan pembelajaran yakni guru dalam memberikan pertanyaan belum dapat memilih kata-kata yang dapt dijawab siswa secara bergantian. Penggunaan waktu yang kurang sesuai dan membelajarkan anak sesuai dengan tema belum terlihat. Guru mengalami kesulitan untuk melihat pemahaman seluruh siswa terhadap materi yang sedang dipelajari. Kelebihan pembelajaran yang dilaksanakan oleh guru adalah saat memberikan motivas,i guru menanyakan aktivitas siswa sebelum berangkat sekolah. Hal ini sangat penting bagi siswa dalam memahami kegiatan yang dilakukan pada pagi hari. 


\section{Deskripsi Hasil Siklus II \\ Perencanaan Tindakan}

Berdasarkan refleksi siklus I maka dapat disusun perencanaan pada siklus II. Perencanaan pada siklus II ini lebih dititik beratkan pada manajemen waktu yang harus dikelola dengan baik oleh guru. Guru harus dapat mengetahui bagian mana dari langkah pembelajaran yang membutuhkan waktu agak panjang dan bagian mana yang membutuhkan waktu agak pendek. Langkah-langkah pembelajaran tematik harus di perjelas guru.

\section{Pelaksanaan Tindakan}

Langkah-langkah pembelajaran yang dilaksanakan guru pada Siklus II ini yakni, guru memulai kegiatan pembelajaran dengan melakukan motivasi pada siswa. Motivasi yang dilakukan guru kepada siswa dengan melakukan tanyajawab. Tanyajawab yang dilakukan seputar pengalaman siswa melakukan perjalanan dari rumah ke sekolah. Setelah itu, guru menyiapkan kosa kata yang lebih dari tiga kata, hal ini cukup rumit bagi siswa. Kosakata ini harus dibaca siswa terlebih dahulu agar mereka dapat memahaminya. Kosakata ini lebih membutuhkan perhatian dari siswa. Pada langkah pembelajaran ini guru memberikan waktu yang cukup panjang, karena tidak semua siswa dapat memahami dengan cepat kosakata yang dimilikinya.

Kegiatan berikutnya guru lebih meningkatkan kemampuan siswa dengan menyiapkan kalimat kalimat berpola sederhana (SPO) yang harus dibaca siswa tanpa bantuan alat peraga kartu huruf berwarna. Kegiatan pada langkah kedua pada prinsipnya sama dengan langkah pertama, hanya materi kosa kata yang menjadi bahan belajar lebih rumit. Hal ini dimaksudkan untuk memperkaya kosakata serta meningkatkan motivasi dan keterlatihan siswa dalam membaca kalimat-kalimat sederhana dengan pola kalimat S-P-O.

\section{Hasil Pengamatan}

Hasil pengamatan dapat dilihat bahwa kegiatan pembelajaran yang dilakukan siswa tidak terlihat tergesa-gesa. Guru sudah dapat mengelola waktu dengan baik. Pengelolaan waktu yang tepat dapat membantu siswa memahami kosakata yang dipelajari. Berdasarkan hasil belajar siswa pada siklus II ini terdapat peningkatan yaitu rata-rata 83,40, bahwa siswa sudah mulai bisa membaca dan menyusun huruf menjadi katakata yang sederhana. Karena hasil belajar dan motivasi siswa untuk membaca sudah meningkat dibandingkan pada siklus sebelumnya, maka penelitian cukup dilakukan pada siklus II saja. Hasil belajar siswa dapat dilihat pada tabel berikut ini.

Tabel 2

\begin{tabular}{lllll} 
& \multicolumn{4}{c}{$\begin{array}{c}\text { Distribusi Hasil Belajar Secara Persentase pada Siklus II } \\
\text { Siswa Kelas I SDN 08 }\end{array}$} \\
No & Nilai & Frekuensi & \% Frekuensi & Kategori Motivasi \\
\hline $\mathbf{1}$ & 100 & 5 & $20 \%$ & Sangat Tinggi \\
$\mathbf{2}$ & 90 & 5 & $20 \%$ & Tinggi \\
$\mathbf{3}$ & 80 & 5 & $20 \%$ & Cukup Tinggi \\
$\mathbf{4}$ & $70-75$ & 8 & $32 \%$ & Sedang \\
$\mathbf{5}$ & 60 & 2 & $8 \%$ & Cukup \\
\hline TOTAL & & 25 & $100 \%$ & \\
\hline
\end{tabular}

Frekuensi data pada siklus II ini diketahui kategori kurang tidak ada, nilai 60 dimiliki oleh siswa sebanyak 2 orang dengan persentase $8 \%$. Ada 8 orang siswa yang mendapatkan nilai antara 70-75 dengan persentasi frekuensi sebesar 32\%. Frekuensi 20\% terdapat siswa yang memiliki nilai 80 s.d 100 dengan jumolah siswa sebanyak 15 orang. Hasil pembelajaran yang dapat dilihat adalah motivasi siswa dalam belajar cukup tinggi. Ada sebanyak 15 orang siswa yang memiliki motivasi yang cukup tinggi.

\section{Refleksi}

Refleksi terhadap hasil pengamatan di atas ditemukan bahwa pembelajaran dengan menggunakan kartu yang berwarna pada setiap huruf dapat meningkatkan motivasi dan hasil belajar siswa kelas I SDN 08 Nan Sabaris. Hal ini terbukti dari perolehan hasil belajar membaca yang meningkat dari sikulus I ke siklus II. 


\section{Pembahasan}

Membaca merupakan keterampilan awal yang harus dikuasai oleh siswa. Membaca bukan hanya mengucapkan bahasa lisan / lambang bunyi bahasa, melainkan juga menangani dan memahami isi tulisan. Dengan demikian hakekat membaca merupakan suatu bentuk komunikasi tulis (Suyatno:2004). Membantu siswa supaya dapat belajar membaca dengan cepat, salah satunya menggunakan media. Media merupakan alat bantu apa saja yang dapat dijadikan sebagai penyalur pesan guna mencapai suatu tujuan pembelajaran (Djamarah:1995:136:Syaiful Bahri:1995). Salah satu media yang dapat digunakan adalah alat peraga kartu huruf. Alat peraga kartu huruf ini sangat menarik perhatian siswa karena berwarna warni. Siswa kelas I suka dengan warna warni karena mereka masih berada pada tahap berfikir konkret. Saat melihatkan kartu huruf kepada siswa, guru juga menyampaikan bunyi huruf tersebut. Setelah itu siswa dapat menyusun kartu huruf menjadi kata.

Berdasarkan pemaparan hasil penelitian yang telah dilakukan, maka diketahui bahwa dengan menggunakan alat peraga berupa kartu huruf berwarna, secara klasikal hasil belajar siswa mengalami peningkatan. Hanya saja sebagian kecil siswa yang masih kurang termotivasi untuk menuyusun kartu huruf dan membaca kembali huruf yang telah disusun berdasarkan pola kata yang sesuai. Secara individual hasil belajar sebagian besar siswa mengalami peningkatan dan sebagian kecil lainnya ada yang tetap dan ada yang tidak stabil. Sedangkan motivasi siswa juga meningkat. Biasanya siswa yang sulit untuk belajar membaca akan malas, tetapi dengan menggunakan kartu huruf keadaan menjadi terbalik.

\section{KESIMPULAN DAN SARAN}

Kesimpulan

Berdasarkan temuan penelitian dan pembahasan dapat ditarik kesimpulan sebagai berikut:

a. Penggunaan alat peraga kartu huruf dapat meningkatkan keterampilan siswa dalam membaca kata-kata secara klasikal maupun secara individual.

b. Contoh-contoh yang diberikan lebih dekat dengan dunia nyata siswa agar mereka termotivasi untuk belajar.

c. Penggunaan alat peraga kartu huruf dapat meningkatkan motivasi siswa dalam belajar.

\section{Saran-saran}

Berdasarkan hasil kesimpulan di atas maka dapat disarankan beberapa hal sebagai berikut:

a. Penggunaan alat peraga kartu huruf harus disesuaikan dengan jumlah alat peraganya.

b. Sebaiknya alat peraga kartu huruf dapat digunakan dengan perbandingan 1:1

c. Guru sebaiknya mengelola waktu dengan tepat agar siswa dapat lebih mudah menyusun kartu huruf sesuai dengan kartu yang dimilikinya

\section{DAFTAR PUSTAKA}

Atmazaki. 2006. Kiat-kiat Menyorong dan Penyunting. Padang : Citra Budaya.

Tabrani Rusyam. dkk. 1992.Pendekatan Dalam Proses Belajar Mengajar. Bandung : PT. Remaja

Rosdakarya.

Djamarah. 2002. Strategi Belajar Mengajar. Jakarta : Rineka Cipta

Endraswara, Suwardi. 2005. Metode dan Teori Pengajaran Sastra. Yogyakarta: Buana Pustaka.

Muhardi dan Hasanuddin W.S. 2006. Prosedur Analisis Fiksi : Kajian Strukturalisme. Padang : Citra Budaya.

Nana Sudjana dan Ahmad Rivai. 1990. Media Pengajaran, (Penggunaan dan Pembuatannya). Bandung : CV Sinar Baru.

Syaiful Bahri dan Aswan Zain. 1995. Strategi Belajar Mengajar. Banjarmasin : Rineka Cipta.

Suharsimi Arikunto, dkk. 2006. Penelitian Tindakan Kelas. Jakarta : BumiAksara.

Suyatno. 2004. Teknik Pembelajaran Bahasa dan Sastra. Surabaya : Penerbit SIC. 